\title{
Wastes to Reduce Emissions from Automotive Diesel Engines
}

\author{
Manuel Jiménez Aguilar \\ Instituto de Investigación y Formación Agraria y Pesquera, Consejería de Agricultura y Pesca, Junta de Andalucía, \\ Camino de Purchil s/n, P.O. Box 2027, 18080 Granada, Spain \\ Correspondence should be addressed to Manuel Jiménez Aguilar; manuel.jimenez.aguilar@juntadeandalucia.es
}

Received 2 September 2013; Revised 18 December 2013; Accepted 1 January 2014; Published 10 February 2014

Academic Editor: Brajesh Dubey

Copyright ( $\odot 2014$ Manuel Jiménez Aguilar. This is an open access article distributed under the Creative Commons Attribution License, which permits unrestricted use, distribution, and reproduction in any medium, provided the original work is properly cited.

\begin{abstract}
The objective of the study was actually the investigation of the effect of various treatments on the ability of urine in absorbing greenhouse gases. Urine alone or mixed with olive-oil-mill waste waters $(\mathrm{O})$, poultry litter $(\mathrm{P})$, or sewage sludge $(\mathrm{S})$ was used on the absorption of $\mathrm{CO}_{2}$ and $\mathrm{NO}_{x}$ from diesel exhaust. The absorption coefficient $\left(0.98-0.29 \mathrm{~g} \mathrm{CO}_{2} / \mathrm{grNH}_{4}\right)$ was similar to other solvents such as ammonia and amines. The ranges of $\mathrm{CO}_{2}$ absorption(1.7-5.6) $\mathrm{g} / \mathrm{l}$ and NO reduction (0.9-3.7) $\mathrm{g} / \mathrm{l}$ in six hours indicate that on average 20 litres of urine could be needed to capture $\mathrm{CO}_{2}$ and $\mathrm{NO}_{x}$ vehicle emissions from each covered kilometre. The best results of $\mathrm{CO}_{2}$ absorption and $\mathrm{NO}_{x}$ reduction were for urine mixed with $\mathrm{O}, \mathrm{P}$ and urine alone. These wastes could be used to capture $\mathrm{CO}_{2}$ and $\mathrm{NO}_{x}$ from automotive diesel engines to reduce gas emissions. The proposed strategy requires further research to increase $\mathrm{CO}_{2}$ absorption and reduce the risks associated with waste-water reuse.
\end{abstract}

\section{Introduction}

Diesel exhaust consists of a mixture of $\mathrm{CO}_{2}, \mathrm{CO}$, and nitrogen oxides $\left(\mathrm{NO}, \mathrm{NO}_{2}\right)$. In two agricultural tractors, using a portable exhaust-emission analyser, Markisz et al. [1] indicated emission values of $\mathrm{CO}_{2}$ of $40-80 \mathrm{~g} / \mathrm{L}, \mathrm{NO}_{x}$ of $0.4-1 \mathrm{~g} / \mathrm{L}$, and $\mathrm{CO}$ of $0.2-0.8 \mathrm{~g} / \mathrm{L}$. Carbon dioxide is the major greenhouse gas in the world that needs to be reduced. There are various technologies used to separate $\mathrm{CO}_{2}$ from flue gas. These include chemical solvent methods, physical absorption methods, cryogenic methods, membrane systems, biological fixation, and the $\mathrm{O}_{2} / \mathrm{CO}_{2}$ combustion process. The chemical solvent methods are generally recognized as the most effective technologies at present [2].

Nitrogen oxides $\left(\mathrm{NO}_{x}\right)$ are considered to be a major source of air pollution and contribute greatly to photochemical smog, acid rain, ozone depletion, and the greenhouse effect. $\mathrm{NO}_{x}$ in diesel exhaust is usually composed of $>90 \%$ NO.

Reduction of nitric oxide flue gas emissions is practised commercially both by the homogeneous process called thermal $\mathrm{NO}_{x}$ reduction and by heterogeneous processes under the commonly used term "selective catalytic reduction" (SCR). Thermal reduction is usually operated around $900^{\circ} \mathrm{C}$, whereas SCR is typically operated at $350^{\circ} \mathrm{C}$ [3]. Commercial catalysts are honeycomb monolith structures constituted by vanadia and tungsta, the active components, supported on titania [4].

Selective catalytic reduction using urea as a reducing agent has been investigated for about 10 years and currently is a well-established technique to diminish $\mathrm{NO}_{x}$ emissions originating from heavy vehicles. According to Koebel et al. [5] the main reactions of $\mathrm{NO}$ with ammonia and urea produce $\mathrm{N}_{2}, \mathrm{H}_{2} \mathrm{O}$, and $\mathrm{CO}_{2}$ :

$$
\begin{gathered}
4 \mathrm{NH}_{3}+4 \mathrm{NO}+\mathrm{O}_{2} \longrightarrow 4 \mathrm{~N}_{2}+6 \mathrm{H}_{2} \mathrm{O} \\
2 \mathrm{CO}\left(\mathrm{NH}_{2}\right)_{2}+4 \mathrm{NO}+\mathrm{O}_{2} \longrightarrow 4 \mathrm{~N}_{2}+4 \mathrm{H}_{2} \mathrm{O}+2 \mathrm{CO}_{2}
\end{gathered}
$$

A new mechanism of reaction has been proposed by Nova et al. [4]

$$
\begin{gathered}
\mathrm{NO}+\mathrm{NO}_{2} \longrightarrow \mathrm{N}_{2} \mathrm{O}_{3} \\
\mathrm{~N}_{2} \mathrm{O}_{3}+\mathrm{H}_{2} \mathrm{O}+2 \mathrm{NH}_{3} \longrightarrow 2 \mathrm{NH}_{4} \mathrm{NO}_{2} \longrightarrow 2 \mathrm{~N}_{2}+4 \mathrm{H}_{2} \mathrm{O}
\end{gathered}
$$

$\mathrm{NO}_{x}$ removal by urea over heterogeneous catalyst as well as in the gas phase (homogeneous reaction) has been known to be 
very effective to reduce the concentration of such a pollutant. However, the process requires slightly high temperature to decompose urea into $\mathrm{NH}_{3}$ and facilitate the surface reaction over the catalyst [6].

There is considerable practical interest in developing a modified thermal reduction process that would operate efficiently at lower temperature.

Several investigators refer to such reduction process as "selective non-catalytic reduction" (SNR). SNR refers to $\mathrm{NO}_{x}$ reduction by means of ammonia (or other reductants) in the presence of mineral surfaces [3]. So, activated carbon was proved to have high catalytic activity for SCR of $\mathrm{NO}_{x}$ with $\mathrm{NH}_{3}$ at low temperature. The reduction of $\mathrm{NO}_{x}$ in air was attempted with urea supported on the activated carbon at room temperature [6].

The mechanism for $\mathrm{NO}_{x}$ reduction over mineral surfaces may be similar to a mechanism that has been proposed for $\mathrm{V}_{2} \mathrm{O}_{5} / \mathrm{TiO}_{2}$-SCR catalysts. These main features are the adsorption of $\mathrm{NH}_{3}$ as $\mathrm{NH}_{4}$ on the surface, adsorption, and oxidation of $\mathrm{NO}$ to $\mathrm{NO}_{2}$ on the surface, and formation and desorption of the main reaction products, $\mathrm{N}_{2}$ and $\mathrm{H}_{2} \mathrm{O}$ [3].

The main objective pursued in our current study is to establish a process for removal of $\mathrm{CO}_{2}$ and $\mathrm{NO}_{x}$ at room temperature without catalysts with relatively low-cost and low-energy requirements. For that, we proposed the hydrolysed urine.

The hydrolysis of urea is catalysed by the enzyme urease, an enzyme of which many microorganisms present in the waste-water solution possess. During the hydrolysis $\mathrm{pH}$ is increased and $\mathrm{NH}_{4}$ is produced:

$$
\mathrm{CO}\left(\mathrm{NH}_{2}\right)_{2}+3 \mathrm{H}_{2} \mathrm{O} \longrightarrow 2 \mathrm{NH}_{4}+\mathrm{HCO}_{3}+\mathrm{OH}
$$

$\mathrm{NH}_{4}$ is in equilibrium with dissolved ammonia:

$$
\mathrm{NH}_{4}+\mathrm{OH} \longrightarrow \mathrm{NH}_{3}+\mathrm{H}_{2} \mathrm{O}
$$

The $\mathrm{pKa}$ value for this equilibrium is 9.3 at $25^{\circ} \mathrm{C}$.

At the same time dissolved ammonia is in equilibrium with gaseous ammonia. Thus, the decomposition of urea will lead to an increase of $\mathrm{NH}_{4}$ and $\mathrm{pH}$, and hence there will be a risk of losses of nitrogen through ammonia evaporation [7].

The ammonia from urine can be used to capture $\mathrm{CO}_{2}$ gas and produce ammonium bicarbonate [8]:

$$
\mathrm{CO}_{2}(\mathrm{~g})+\mathrm{NH}_{3}(\mathrm{aq})+\mathrm{H}_{2} \mathrm{O}(\mathrm{l}) \longrightarrow \mathrm{NH}_{4} \mathrm{HCO}_{3}(\mathrm{aq})
$$

If the aqueous ammonia is the agent that can simultaneously remove $\mathrm{CO}_{2}, \mathrm{SO}_{2}$, and $\mathrm{NO}_{x}$, plus $\mathrm{HCl}$ and $\mathrm{HF}$ that may exist in the flue gas [9], it would possible to think that some organic wastes such as P [10] and S [11] like sources of ammonia (11 g/Kg, $2 \mathrm{~g} / \mathrm{Kg}$, resp.) could be added urine and used to capture $\mathrm{CO}_{2}$ and reduce $\mathrm{NO}_{x}$ emissions from automotive diesel engines.

The acidification is a method to inhibit decomposition of urea and avoid ammonia losses [7]. So, addition of a low percentage of $\mathrm{O}($ acid $\mathrm{pH})$ could stabilize the $\mathrm{CO}_{2}$ absorbed to reduce urine $\mathrm{pH}$ and thus ammonia volatilization [12].

Human urine, $\mathrm{O}$, and $\mathrm{P}$ are all materials that are produced in large quantities as wastes of other processes and can be obtained at reasonable prices. Separating urine from wastewater at the source reduces the costs of extensive waste water treatment. The sanitation treatment of solid, dry human faeces would be a much easier process, since it would be more aerobic and the amount of human faeces is low compared to the amount of urine [13]. Recovering the nutrients from urine and other wastes and reusing them for agricultural purposes offer the added benefits of resource savings [14].

The aim of the present work was to investigate the ability of $\mathrm{NH}_{4}$ from $\mathrm{O}, \mathrm{P}$, and $\mathrm{S}$ to increase the $\mathrm{CO}_{2}$-absorption capacity of urine in automotive diesel engines. Also, the effect of bubbled wastes on the germination of tomato seed was tested.

\section{Materials and Methods}

Five samples of hydrolysed urine were used, at $\mathrm{pH} 9,8.4$, $8.9,9,8.4$, and electroconductivity (EC) $25,15,42,25$, and $15 \mathrm{dSm}^{-1}$, respectively. The O, collected from St. Anthony oil mill of Viznar (Granada, Spain) in January 2011, had a $\mathrm{pH}$ of $4.2, \mathrm{EC}$ of $12 \mathrm{dSm}^{-1}, \mathrm{PO}_{4}-0.19 \mathrm{~g} / \mathrm{L}, \mathrm{K}-7.9 \mathrm{~g} / \mathrm{L}$, and total polyphenols-3.1 $\mathrm{g} / \mathrm{L}$.

Five samples (A, B, C, D, and E) of hydrolysed urine were used as controls. The different treatments were BP-urine mixed with $0.5 \% \mathrm{P}$ in weight; CS-urine mixed with $0.5 \% \mathrm{~S}$ in weight; DO-urine mixed with $1 \% \mathrm{O}$ in volume; EPO-urine mixed with $2 \% \mathrm{O}$ in volume and $1 \% \mathrm{P}$ in weight. All samples were stored in brown bottles with two replicates for each treatment. Half samples (A1, BP1, CS1, DO1, and EPO1) were bubbled with fumes from the exhaust pipe of an agricultural tractor (model 996E-Pasquali). For that, each sample was introduced in a 2.5 litre plastic bottle. A curved tube of forge iron communicated the exhaust pipe with the bottom of the bottle. To avoid heating, the ignition engine was switched on/off to intervals of 20 minutes. So, the bubbling time for each sample was 6 hours ( 2 hours each day during 3 days).

In the end the $\mathrm{pH}$ of bubbled samples decreased to around 8.0. All the samples were stored in 1-litre bottles open to air in the laboratory for 5 months. According to Hoglund et al. [15], urine stored for at least 6 months may be considered safe to use as a fertilizer for any crop.

Every two weeks, the $\mathrm{pH}, \mathrm{CO}_{2}, \mathrm{NH}_{4}, \mathrm{PO}_{4}$, and $\mathrm{K}$ values as well as the $\mathrm{EC}$ of each bottle were measured. The $\mathrm{pH}$ was monitored using a $\mathrm{pH} /$ ion meter and $\mathrm{EC}$ using a conductivity meter (both Crison 2002). The $\mathrm{CO}_{2}$ was analysed following the procedure reported by Lin and Chan [16]. For this, after determining the initial $\mathrm{pH}$ of the sample, a $2 \mathrm{~mL}$ urine sample was pipetted into a vial containing $10 \mathrm{~mL}$ of $0.1 \mathrm{~N}$ $\mathrm{HCl}$ and the mixture was placed in a boiling water bath for $10 \mathrm{~min}$ to expel the $\mathrm{CO}_{2}$. Allow the sample to cool to room temperature, add a magnetic stirrer, and titrate with $0.1 \mathrm{~N} \mathrm{NaOH}$. Note the volume of $\mathrm{NaOH}$ added to achieve the initial $\mathrm{pH}$ of the sample. A blank containing $2 \mathrm{~mL}$ of distilled water was treated in an identical way. The amount of $\mathrm{CO}_{2}$ in $\mathrm{mEq} / \mathrm{L}$ was determined by multiplying the difference in the volumes of $\mathrm{NaOH}$, required to titrate the blank and sample, by the normality of $\mathrm{NaOH}$. The $\mathrm{NH}_{4}$ was analysed following Nelson [17]. The $\mathrm{K}^{+}$was analysed by direct reading in a flame 
TABLE 1: Main effects of diesel exhaust on the $\mathrm{pH}, \mathrm{EC}, \mathrm{PO}_{4}, \mathrm{~K}, \mathrm{CO}_{2}$ and $\mathrm{NH}_{4}$ (average values for 14 measurements).

\begin{tabular}{|c|c|c|c|c|c|c|c|c|c|}
\hline Treatment & $\mathrm{pH}$ & $\begin{array}{c}\mathrm{EC} \\
(\mathrm{dS} / \mathrm{m}) \\
\end{array}$ & $\begin{array}{c}\mathrm{PO}_{4} \\
(\mathrm{mg} / \mathrm{L})\end{array}$ & $\begin{array}{c}\mathrm{K} \\
(\mathrm{g} / \mathrm{L})\end{array}$ & $\begin{array}{l}\mathrm{CO}_{2} \\
(\mathrm{~g} / \mathrm{L}) \\
\end{array}$ & $\begin{array}{l}\mathrm{NH}_{4} \\
(\mathrm{~g} / \mathrm{L})\end{array}$ & $\begin{array}{c}\mathrm{CO}_{2} \text {-Absorption } \\
(\mathrm{g} / \mathrm{L})\end{array}$ & $\begin{array}{cl}\mathrm{NH}_{4} & \text { Reduction } \\
(\mathrm{g} / \mathrm{L})\end{array}$ & $\begin{array}{c}\text { Absorption } \\
\text { coefficient }\end{array}$ \\
\hline $\bar{A}$ & $8.89^{\mathrm{b}}$ & $27.9^{\mathrm{a}}$ & $139^{\mathrm{a}}$ & $1.7^{\mathrm{a}}$ & $4.5^{\mathrm{a}}$ & $5.2^{\mathrm{a}}$ & & & \\
\hline $\mathrm{A} 1$ & $8.36^{\mathrm{a}}$ & $28.9^{\mathrm{b}}$ & $164^{\mathrm{a}}$ & $1.7^{\mathrm{a}}$ & $8.5^{\mathrm{b}}$ & $4.8^{\mathrm{a}}$ & $+4.06^{\mathrm{b}}$ & $-0.42^{\mathrm{c}}$ & $0.87^{\mathrm{cd}}$ \\
\hline B & $8.89^{\mathrm{b}}$ & $22.1^{\mathrm{a}}$ & $138^{\mathrm{a}}$ & $1.3^{\mathrm{a}}$ & $4.2^{\mathrm{a}}$ & $4.0^{\mathrm{a}}$ & & & \\
\hline BP & $8.81^{\mathrm{b}}$ & $24.5^{\mathrm{b}}$ & $135^{\mathrm{a}}$ & $1.3^{\mathrm{a}}$ & $5.5^{\mathrm{b}}$ & $4.5^{\mathrm{b}}$ & & & \\
\hline BP1 & $8.17^{\mathrm{a}}$ & $25.1^{\mathrm{b}}$ & $144^{\mathrm{a}}$ & $1.3^{\mathrm{a}}$ & $8.2^{c}$ & $4.0^{\mathrm{a}}$ & $+2.63^{\mathrm{a}}$ & $-0.47^{\mathrm{c}}$ & $0.66^{\mathrm{bc}}$ \\
\hline $\mathrm{C}$ & $8.97^{\mathrm{b}}$ & $42.2^{\mathrm{b}}$ & $178^{\mathrm{a}}$ & $3.3^{\mathrm{a}}$ & $10.5^{\mathrm{a}}$ & $8.5^{\mathrm{b}}$ & & & \\
\hline CS & $8.94^{\mathrm{b}}$ & $43.3^{\mathrm{c}}$ & $196^{\mathrm{b}}$ & $3.3^{\mathrm{a}}$ & $10.8^{\mathrm{a}}$ & $8.8^{\mathrm{b}}$ & & & \\
\hline CS1 & $8.37^{\mathrm{a}}$ & $39.1^{\mathrm{a}}$ & $196^{\mathrm{b}}$ & $3.5^{\mathrm{a}}$ & $12.2^{\mathrm{b}}$ & $6.1^{\mathrm{a}}$ & $+1.67^{\mathrm{a}}$ & $-2.75^{\mathrm{a}}$ & $0.29^{\mathrm{a}}$ \\
\hline $\mathrm{DO}$ & $8.95^{\mathrm{b}}$ & $39.0^{\mathrm{b}}$ & $174^{\mathrm{a}}$ & $3.0^{\mathrm{a}}$ & $5.3^{\mathrm{a}}$ & $7.6^{b}$ & & & \\
\hline DO1 & $8.36^{\mathrm{a}}$ & $36.8^{\mathrm{a}}$ & $174^{\mathrm{a}}$ & $3.1^{\mathrm{a}}$ & $10.9^{\mathrm{b}}$ & $5.9^{\mathrm{a}}$ & $+5.62^{\mathrm{c}}$ & $-1.72^{\mathrm{b}}$ & $0.98^{\mathrm{d}}$ \\
\hline$E$ & $8.95^{\mathrm{c}}$ & $26.7^{\mathrm{a}}$ & $159^{b}$ & $1.4^{\mathrm{a}}$ & $5.1^{\mathrm{a}}$ & $5.3^{\mathrm{b}}$ & & & \\
\hline EPO & $8.81^{\mathrm{b}}$ & $29.5^{\mathrm{c}}$ & $131^{\mathrm{a}}$ & $1.8^{\mathrm{b}}$ & $6.7^{\mathrm{b}}$ & $5.6^{\mathrm{b}}$ & & & \\
\hline EPO1 & $8.22^{\mathrm{a}}$ & $28.8^{\mathrm{b}}$ & $152^{\mathrm{b}}$ & $1.9^{\mathrm{b}}$ & $8.4^{\mathrm{c}}$ & $4.4^{\mathrm{a}}$ & $+1.75^{\mathrm{a}}$ & $-1.25^{\mathrm{b}}$ & $0.42^{\mathrm{ab}}$ \\
\hline
\end{tabular}

Different letters $^{(\mathrm{a}, \mathrm{b}, \mathrm{c}, \mathrm{d})}$ within a column indicate significant differences between treatments at level of significance $(P<0.05)$ according to Tukey's test.

photometer (model METEOR-NAK II). $\mathrm{PO}_{4}$ analysis was made by the method of Watanabe and Olsen in a UV/VIS spectrometer (model UNICAM 5625) [18].

2.1. Agricultural Test. In this work, the effects of bubbled wastes on the tomato-seed germination were tested. Preciado et al. [19] studied tomato seedlings watered with four urine dilutions with different levels of EC. The results showed a statistical significance in the growth parameters with the nutrient solution at the level of $1 \mathrm{dS} \mathrm{m}{ }^{-1}$.

On the other hand, according to Komilis et al. [20], the $\mathrm{O}$ phytotoxicity decreased with increased $\mathrm{O}$ dilution with water. The higher the dilution the lower the phytotoxicity. To achieve a EC nearby to $1-2 \mathrm{dS} \mathrm{m}^{-1}$ our bubbled samples were diluted to a ratio of $1: 10$ and $1: 20$ using tap water. Three seeds from tomato (Solanum lycopersicum) variety Tres Cantos were sown in each plastic cups measuring $7 \mathrm{~cm} \times$ $5 \mathrm{~cm}$. The plants were grown in a mixture of sand $(20 \mathrm{~g})$ and olive stone $(5 \mathrm{~g})$. On the first day, $20 \mathrm{~mL}$ of tap water was uniformly added to each cup. On alternate days, $5 \mathrm{~mL}$ of bubbled wastes dilutions $1 / 10$ or $1 / 20$ or tap water (control) was added to each cup. All samples, including the control, were run in duplicate. The cups were kept in the laboratory for three weeks.

The results were subjected to an analysis of variance and comparison of means using the PC computer program Statistic 8.0 (Analytical Software, FL, USA). Also, the figures were plotted with this program.

\section{Results and Discussion}

The average values of $\mathrm{pH}, \mathrm{EC}, \mathrm{CO}_{2}, \mathrm{NH}_{4}, \mathrm{PO}_{4}$, and $\mathrm{K}$ of each treatment are shown in Table 1.

The treatments with diesel exhaust increased the $\mathrm{CO}_{2}$ absorption in all samples, indicating that part of $\mathrm{CO}_{2}$ $(1.67-5.62 \mathrm{~g} / \mathrm{L}$ ) was absorbed by the samples (Figure 1).

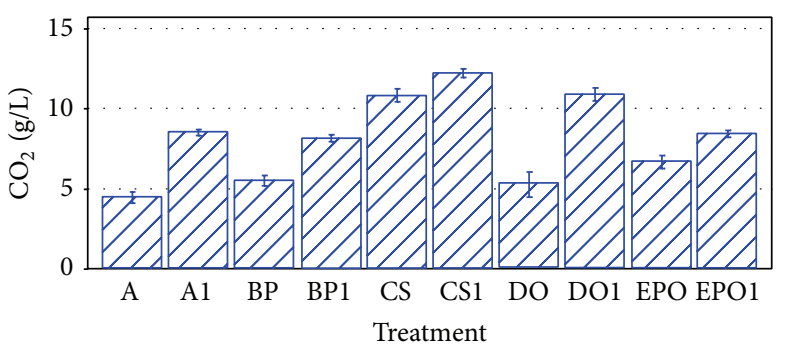

Figure 1: Mean values of $\mathrm{CO}_{2}$.

The treatment with the highest $\mathrm{CO}_{2}$ absorption were $\mathrm{DO} 1$ $(5.62 \mathrm{~g} / \mathrm{L})$ and urine alone $(4.06 \mathrm{~g} / \mathrm{L})$ (see Table 1, Figure 1).

Theoretically according to (5), absorption capacity of ammonia was $2.5\left(44 \mathrm{~g} \mathrm{CO}_{2} / 17 \mathrm{~g} \mathrm{NH}_{3}\right)$. Previous research shows that aqueous ammonia have a higher absorption capacity than that of monoethanolamin (MEA) at the same temperature and pressures. Absorption capacity of aqueous ammonia can be higher than $1 \mathrm{~g} \mathrm{CO}_{2} / \mathrm{g} \mathrm{NH}_{3}$, and MEA is only $0.36 \mathrm{~g} \mathrm{CO}_{2} / \mathrm{g} \mathrm{MEA}$. The $\mathrm{CO}_{2}$ removal efficiency with $1 \%$ aqueous ammonia was $50 \%$ in 1 hour [2] (in our research may be similar).

Our research shows that the absorption capacity of urine was similar to $\mathrm{NH}_{3}$ and MEA (between 0.98 and $0.29 \mathrm{~g} \mathrm{CO}_{2} / \mathrm{g} \mathrm{NH}_{4}$ in 6 hours for treatment DO1 and CS1, resp.).

The higher $\mathrm{CO}_{2}$ absorption for DO1 samples could be explained by the buffering capacity of $\mathrm{O}$. To more buffering capacity there are a smaller variation in $\mathrm{pH}$ for the addition of $\mathrm{CO}_{2}$ with a better stabilization of the $\mathrm{CO}_{2}$ absorbed [3].

Some treatment significantly reduced $\mathrm{NH}_{4}$ contents (see Table 1, Figure 2).

The decrease in $\mathrm{NH}_{4}$ could be explained by assuming, as indicated by Wei et al. [21], that $\mathrm{NO}_{x}$ from flue gas can 


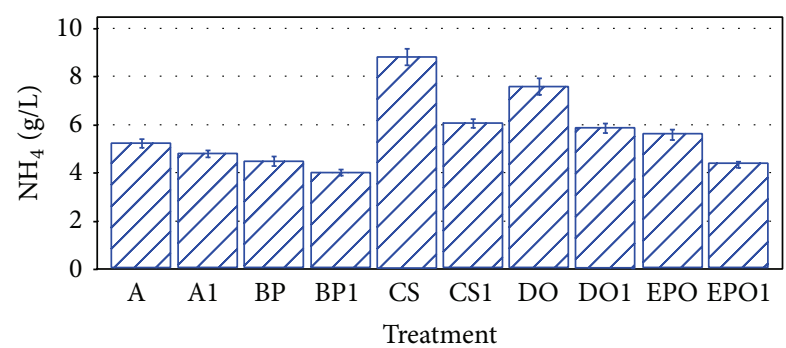

Figure 2: Mean values of $\mathrm{NH}_{4}$.

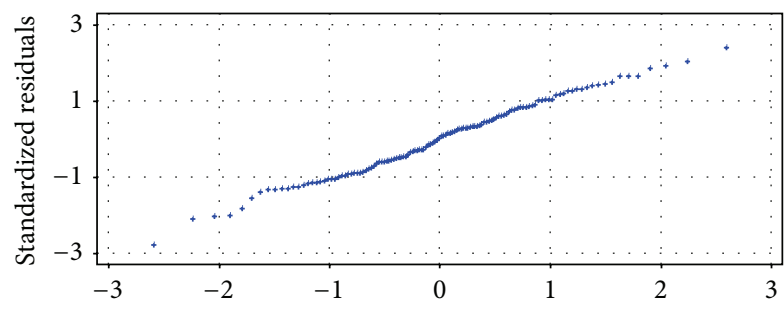

Figure 3: Correlation between $\mathrm{pH}, \mathrm{CO}_{2}, \mathrm{NH}_{4}$.

react with $\mathrm{NH}_{3}$ decomposed from ammonium bicarbonate to produce $\mathrm{N}_{2}$.

The treatments with the lowest $\mathrm{NH}_{4}$ reduction were urine alone $(-0,42 \mathrm{~g} / \mathrm{L})$ and $\mathrm{BP} 1(-0,47 \mathrm{~g} / \mathrm{L})$. The greatest $\mathrm{NH}_{4}$ decrease in CS1 $(-2.75 \mathrm{~g} / \mathrm{L})$ and DO1 $(-1.72 \mathrm{~g} / \mathrm{L})$ samples could be explained according to Buondonno et al. [22] by the fact that some organic wastes can increase immobilization of inorganic or mineralised $\mathrm{N}$. Moreover, the fact that $\mathrm{NH}_{4}$ ion linked with $\mathrm{O}$ in the presence of carbonates would reduce $\mathrm{NH}_{4}$ in DO1 and EPO1 samples [12].

If we consider that $\mathrm{NH}_{4}$ lost $(0.4-1.7 \mathrm{~g} / \mathrm{L})$ in our research was due to $\mathrm{NO}_{x}$ elimination then theoretically between $0.7-3 \mathrm{~g} / \mathrm{L}$ of $\mathrm{NO}$ could be eliminated in 6 hours. So, our $\mathrm{NO}_{x}$ removal efficiency may be similar $80 \%$ NO removed in $20-40$ hours reported by Shirahama et al. [6].

The dissolved exhaust fumes lowered the $\mathrm{pH}$ of the urine mixtures from 9.0 to 8.3 due to the formation of carbonic acid. The lowering of the $\mathrm{pH}$ could be explained by the absorption of $\mathrm{CO}_{2}$ on the one hand and the reduction of $\mathrm{NH}_{4}$ values on the other hand.

$\mathrm{NH}_{4}$ volatilization increased with the $\mathrm{pH}$, so that all the factors that tended to lower the $\mathrm{pH}$ reduced $\mathrm{NH}_{4}$ losses [23]. Therefore all treatments to reduce the $\mathrm{pH}$ proved useful to $\mathrm{NH}_{4}$ conservation.

For all the samples, the $\mathrm{pH}$ variations could be explained in function of the $\mathrm{CO}_{2}$ and $\mathrm{NH}_{4}$ increases. So, the $\mathrm{pH}, \mathrm{CO}_{2}$ and $\mathrm{NH}_{4}$ showed a statistically significant relationship $(P<$ 0.0001 ) (correlation coefficient 0.697 ) at the $95 \%$ confidence level (see Figure 3); $\mathrm{NH}_{4}$ contributed nearly 2 -fold more than $\mathrm{CO}_{2}$ to the $\mathrm{pH}$ variation:

$$
\mathrm{pH}=8.41+0.15 \mathrm{NH}_{4}-0.08 \mathrm{CO}_{2}
$$

The increase in conductivity generated by $\mathrm{CO}_{2}$ dissolution and ionisation in water was reduced by the decomposition of urea and $\mathrm{NH}_{4}$ due to reactions with $\mathrm{NO}_{x}$ [5].

In our laboratory, $\mathrm{CO}_{2}$ and $\mathrm{NH}_{4}$ contents of all samples treated with diesel exhaust remained conservative for more than five months. The better treatments (higher $\mathrm{CO}_{2}$ absorption, with lower $\mathrm{NH}_{4}$ reduction) were $\mathrm{DO}, \mathrm{A}$, and $\mathrm{BP}$.

Tables for different vehicles (gasoline, diesel) indicate on average emissions values of $140 \mathrm{~g} \mathrm{CO}_{2}$ and $2 \mathrm{~g} \mathrm{NO}_{x}$ for kilometre. With these values between 15 and 25 litres of urine could be need to capture $\mathrm{CO}_{2}$ and $\mathrm{NO}_{x}$ mean vehicle emissions from each covered kilometre. The urine produced by a family could be stored at home and be useful to reduce own vehicle emissions into towns.

Nevertheless, the advantages of this technology are undeniable: a process for removal of $\mathrm{CO}_{2}$ and $\mathrm{NO}_{x}$ at room temperature without catalysts with relatively low-cost and low-energy requirements.

Source separation of human urine is based on toilets equipped with two bowls, a front one for the collection of urine and a rear one for faecal material. Separating urine from faeces could have environmental advantages such as the reduction of water consumption for human excrement disposal (make savings 10-20 litres per person and day). Before, the faeces collected separately could be mixed at home with urban organic wastes to produced organic compost. So, both urine bubbled with greenhouse gases and faeces could be used as new fertilizers. The atmospheric CO2 could be absorbed in the urine solutions and added to alkaline soils could be deposited as carbonate minerals

Some limitations: Urine should be stored at home and carried in the vehicle in a pressure container. Before $\mathrm{NH}_{4}$ contents in urine are variable and depend on diet and ambient temperature which limits the $\mathrm{CO}_{2}$ absorption capacity (about $10 \mathrm{~g}$ by litre of urine).

The urine and other wastes containing urea or ammonium bicarbonate such as $\mathrm{P}$ by itself could be considered sources of ammonia and useful to $\mathrm{CO}_{2}$ and $\mathrm{NO}$ absorption.

3.1. Agricultural Test. The results of the study showed that dilution at the 1:20 level did not significantly diminish the germination or growth of tomato plants for three weeks. Because the overall objective of the source-separation system was to use the wastes as a fertilizer, it would be suitable to test these wastes for different crops over a complete crop cycle. Fertilization with urine and $\mathrm{O}$ has previously been demonstrated to be a feasible method for reducing the environmental impact of $\mathrm{O}$, nitrates, and $\mathrm{CO}_{2}$ [24].

$\mathrm{P}$ and $\mathrm{S}$ could provide $\mathrm{N}$ and other plant nutrients when used as fertilizers $[25,26]$. Whereas part of added $\mathrm{NH}_{4}$ was consumed to eliminate $\mathrm{NO}_{x}$, the added sources of $\mathrm{NH}_{4}(\mathrm{P}$ and $\mathrm{S})$ did not significantly increase $\mathrm{CO}_{2}$ adsorption. Therefore, new wastes, manures, and compost need to be tested with added urine as a means for increasing $\mathrm{NH}_{4}$ contents and $\mathrm{CO}_{2}$ adsorption.

Thus, urine mixed with the above-mentioned wastes could provide all plant nutrients and be recycled by the fertilizer industry. 


\section{Conclusions}

In conclusion, hydrolysed urine mixed with a small percentage (1-2\%) of $\mathrm{O}$ or $\mathrm{P}$ could be considered a stable longterm system for greenhouse-gas absorption. An average of 15-25 litres of these urine mixtures could be needed to capture $\mathrm{CO}_{2}$ and $\mathrm{NO}_{x}$ mean vehicle emissions from each covered kilometre. So, the vehicle exhaust contamination could be reduced. These wastes could be used as fertilizers.

Some wastes similar to urine should be tested as $\mathrm{CO}_{2}$ sinks to produce new carbonated fertilizers. In addition, the reduction of $\mathrm{NO}_{x}$ emissions requires further research to increase the $\mathrm{NH}_{4}$ contents and $\mathrm{CO}_{2}$ absorption.

\section{Conflict of Interests}

The author declares that there is no conflict of interests regarding the publication of this paper.

\section{Acknowledgments}

This study was funded by the Institute of Agricultural Research and Training, Andalusian Government. The author is grateful to the anonymous reviewers for insightful comments which greatlyfi improved the quality of the paper.

\section{References}

[1] J. Markisz, P. Lijewski, and S. Weymann, The Measurement of Exhaust Emissions From the Engines Fitted in Agricultural Tractors Under Real Operating Conditions, International Congress of Heavy Vehicles, Road Trains and Urban Transport, Minsk, Russia, 2010.

[2] J. Liu, S. Wang, B. Zhao, H. Tong, and C. Chen, "Absorption of carbon dioxide in aqueous ammonia," in Proceedings of the 9th International Conference on Greenhouse Gas Control Technologies (GHGT '9), pp. 933-940, November 2008.

[3] P. H. Wallman and R. C. J. Carlsson, "NO$x$ reduction by ammonia the effects of pressure and mineral surfaces," Fuel, vol. 72, no. 2, pp. 187-192, 1993.

[4] I. Nova, C. Ciardelli, E. Tronconi, D. Chatterjee, and B. BandlKonrad, " $\mathrm{NH}_{3}-\mathrm{NO} / \mathrm{NO}_{2}$ chemistry over V-based catalysts and its role in the mechanism of the Fast SCR reaction," Catalysis Today, vol. 114, no. 1, pp. 3-12, 2006.

[5] M. Koebel, M. Elsener, and M. Kleemann, "Urea-SCR: a promising technique to reduce $\mathrm{NO}_{x}$ emissions from automotive diesel engines," Catalysis Today, vol. 59, no. 3, pp. 335-345, 2000.

[6] N. Shirahama, I. Mochida, Y. Korai et al., "Reaction of NO with urea supported on activated carbons," Applied Catalysis B, vol. 57, no. 4, pp. 237-245, 2005.

[7] D. Hellström, E. Johansson, and K. Grennberg, "Storage of human urine: acidification as a method to inhibit decomposition of urea," Ecological Engineering, vol.12, no. 3-4, pp. 253-269, 1999.

[8] M. J. Aguilar, "Urine as a $\mathrm{CO}_{2}$ absorbent," Journal of Hazardous Materials, vol. 213-214, pp. 502-504, 2012.

[9] K. P. Resnik, J. T. Yeh, and H. W. Pennline, "Aqua ammonia process for simultaneous removal of $\mathrm{CO}_{2}, \mathrm{SO}_{2}$ and $\mathrm{NO}_{x}$," International Journal of Environmental Technology and Management, vol. 4, no. 1-2, pp. 89-104, 2004.
[10] D. A. R. Diaz, J. E. Sawyer, and A. P. Mallarino, "Poultry manure supply of potentially available nitrogen with soil incubation," Agronomy Journal, vol. 100, no. 5, pp. 1310-1317, 2008.

[11] J. Martin, R. M. de Imperial, E. Beltrán et al., "Mineralización del nitrógeno contenido en un lodo de depuradora secado térmicamente," Revista Internacional Contaminacion Ambiental, vol. 22, pp. 125-133, 2006.

[12] M. J. Aguilar, "Fixation of ammonium-N and nitrate-N with olive oil mill wastewaters," Environmental Technology, vol. 31, no. 4, pp. 395-398, 2010.

[13] H. Heinonen-Tanski, A. Sjöblom, H. Fabritius, and P. Karinen, "Pure human urine is a good fertiliser for cucumbers," Bioresource Technology, vol. 98, no. 1, pp. 214-217, 2007.

[14] Z. Liu, Q. Zhao, K. Wang, D. Lee, W. Qiu, and J. Wang, "Urea hydrolysis and recovery of nitrogen and phosphorous as MAP from stale human urine," Journal of Environmental Sciences, vol. 20, no. 8, pp. 1018-1024, 2008.

[15] C. Hoglund, T. A. Stenstrom, and N. Ashbolt, "Microbial risk assessment of source-separated urine used in agriculture," Waste Management and Research, vol. 20, no. 2, pp. 150-161, 2002.

[16] S. L. Lin and J. C. M. Chan, "Urinary bicarbonate: a titrimetric method for determination," Clinical Biochemistry, vol. 6, no. 3, pp. 207-210, 1973.

[17] D. Nelson, "Determination of ammonium in $\mathrm{KCl}$ extracts of soils by the salicylate method," Communications in Soil Science and Plant Analysis, vol. 148, pp. 1051-1062, 1983.

[18] F. S. Watanabe and S. R. Olsen, "Test of an Ascorbic Acid Method for determining phosphorus in water and $\mathrm{NaHCO}_{3}$ extracts from soil," Soil Science Society of America Journal, vol. 29, pp. 677-678, 1965.

[19] P. Preciado, A. G. Torres, M. A. Segura et al., "Evaluation of human urine as a source of nutrients in the production of tomato seedlings," Universidad Y Ciencia, vol. 26, no. 2, pp. 171178, 2010.

[20] D. P. Komilis, E. Karatzas, and C. P. Halvadakis, "The effect of olive mill wastewater on seed germination after various pretreatment techniques," Journal of Environmental Management, vol. 74, no. 4, pp. 339-348, 2005.

[21] Z. S. Wei, Z. Y. Du, Z. H. Lin, H. M. He, and R. L. Qiu, "Removal of $\mathrm{NO}_{x}$ by microwave reactor with ammonium bicarbonate and Ga-A zeolites at low temperature," Energy, vol. 32, no. 8, pp. 1455-1459, 2007.

[22] A. Buondonno, E. Coppola, G. Palmieri et al., "Monitoring nitrogen forms in soil/plant systems under different fertilizer managements. A preliminary investigation," European Journal of Agronomy, vol. 7, no. 4, pp. 293-300, 1997.

[23] Z. L. He, A. K. Alva, D. V. Calvert, and D. J. Banks, "Ammonia volatilization from different fertilizer sources and effects of temperature and soil pH," Soil Science, vol. 164, no. 10, pp. 750758, 1999.

[24] M. J. Aguilar, "Olive oil mill wastewater for soil nitrogen and carbon conservation," Journal of Environmental Management, vol. 90, no. 8, pp. 2845-2848, 2009.

[25] D. R. Chadwick, F. John, B. F. Pain, B. J. Chambers, and J. Williams, "Plant uptake of nitrogen from the organic nitrogen fraction of animal manures: a laboratory experiment," Journal of Agricultural Science, vol. 134, no. 2, pp. 159-168, 2000.

[26] T. K. Hartz, J. P. Mitchell, and C. Giannini, "Nitrogen and carbon mineralization dynamics of manures and composts," HortScience, vol. 35, no. 2, pp. 209-212, 2000. 

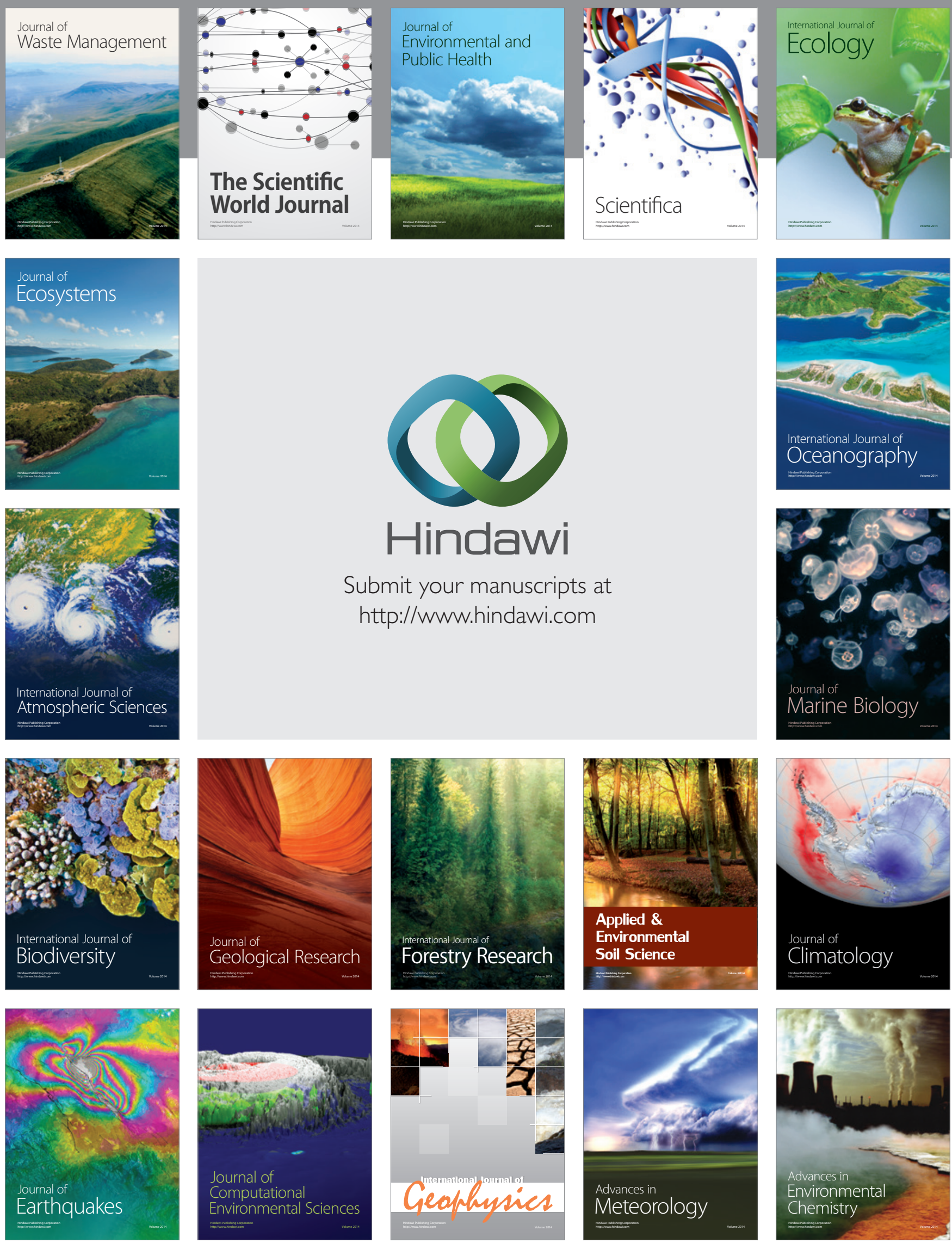